\title{
Identification of organic and biodynamic grape and wine producers in southern Brazil
}

\author{
Narjara Medeiros ${ }^{1, a}$, Lays Machado ${ }^{2}$, and Rodrigo da Silva Lisboa ${ }^{1}$ \\ ${ }^{1}$ UNIPAMPA, Bacharelado em Enologia, Rua 21 de abril, 80, CEP 96450-000, Dom Pedrito, Brasil \\ ${ }^{2}$ IFF Rio Grande do Sul, Tecnologia em Viticultura e Enologia, Avenida Osvaldo Aranha, 540, CEP: 95700-000, Bento \\ Gonçalves, Brasil
}

\begin{abstract}
The concern about health and environmental aspects are increasingly present in our society. In 1976 José Lutzemberger publishes the first Brazilian ecological manifesto. In 2003 the Law 10.831 is approved, which conceptualizes and defines organic agriculture. In 1982, the first Biodynamic Agriculture meeting in Brazil happens, where the construction of the basis for the implementation of biodynamic in Brazilian agriculture started. In 1995 the Brazilian Association of Biodynamic Agriculture is created. The search for organic products - that doesn't use artificial mineral and chemical fertilizers and exploits fertility as a way of fighting diseases and pests - and biodynamic products in the agricultural production unit is understood as a kind of organism also take place in the wine industry. But knowing which producers are involved in this type of activity is still a difficult task for the community, especially due to the informality of some agents. Thus, this paper proposes to identify organic and biodynamic wine producers in southern Brazil; as well as the tools and policies which have encouraged farmers to adopt these practices. Finally, understanding the main obstacles producers find dealing with certifications mechanisms. This region was chosen for being the largest grape and wine producing in the country.
\end{abstract}

\section{Introduction}

Nowadays we se a notorious growth in social-environmental matters reflecting on the consuming market. The rising use of organic and biodynamic products are a straight symptom of that demand being attended by the industries.

The organic agriculture starts its developing and dissemination with Alberth Howard [1], British botanical sent to India on the beginning of the 20th Century as an Agricultural Counselor for the Empire. His studies amongst Indian farmers resulted in the book called "Um testamento Agricola", released in 1943, where is found the firsts descriptions of the Indore Process, composting, and many other forms of sustainable managements. The whole conduct for the crop and animal production is programmed so it potencializes the soil structure, specially the progression of humus. But Howards' contributions trespass composting techniques. As a precursor for agro ecology, he found echoes on Trofobiose's theory, proposed by Francis Chaboussou, revolutionizing the way agriculture has been thought.

Germany, home of the agricultural chemistry, was also home for the most ancestral reaction, crystalized in 1924, known as biodynamic. This movement has on its center, the philosopher Rudolf Steiner, which ideas gave base to many generations of investigations by agronomists and farmers. The immediate motivation for those who invested

\footnotetext{
${ }^{a}$ Corresponding author: narjaramedeiros@gmail.com
}

on that new management was the fast decrease of the crops and the creations submitted to technologies, until now only focused on manure. In this new method, the systemic approach is the priority, understanding the rural properties as organisms [2].

The biodynamic agriculture has as its main goal, to transform the property into an agricultural organism, a place where each component has its activities potencialized (crop, cattle, forests, water sources, living fences, wildlife corridors, windbreaks, and many others). It also works hardly on biological processes by commom practices with the organical agriculture, like green fertilization, composting, crop rotation, agroforestry, ground cover and others. And as a diferential, uses biodynamical preparations, developed with medicinal plants, manure and silica, which are used in a homeopatical way, acting as an stimulation for the activities of the soils organisms on composting and crop quality [3].

All of Steiner's reasoning for his biodynamic postulates, are based on the emancipation concept. Steiner believes that the man, and, to a lesser degree, the animals, could emancipate from the cosmos, the outside world. That doesn't mean the cycle and vibrations of this outside worlds doesn't affect them, in fact it says that those cycles on the human and animal life doesn't have "the same order that those outside circles, although they follow the same periodicity, rhythm but not the coincidence in time" [4]. As a reminder we have one of the most important phenomenon, female periods, on their course are exact 
copies of the Moon's course, but they do not match on dates. There are a lot of delicate phenomena on the human body that are aligned with nature courses as well [3]. But the plants are still, in higher scale, completely inserted on nature's cycle and extraterrestrial. Therefore, it's impossible to understand the vegetal life without considering that what happens on earth is just a reflex from what happens in the cosmos [4].

Biodynamic agriculture has a common ground with all the other organics managements when talking about diversification and integration of vegetables, animals and forests; it adopts the method of recycling of animal and plants residues, composting and uses low solubility and concentration nutrients. The difference between biodynamic agriculture and others are mainly two. First the use of biodynamic preparations, which are substances of animal, vegetal or mineral origin highly solved, that enhances nature forces to revitalize and stimulate plant growth when applied into the soil and over the plants. The second is to program farming operations (planting, pruning, cropping and other treatments) in order with the astral calendar, with observations about moon and planets positioning in comparison with constellations [5].

In Brazil, food safety, sustainable agriculture and changes on production processes where already in discussion since the $70 \mathrm{~s}$, but was only institucionalized around the $90 \mathrm{~s}$, at ECO 92, in Rio de Janeiro. The higher pressure that came from both ways, farmers and the consumers, was in December $23^{\text {rd }}$ in 2003, with Law 10.831 , which states basic rules for the organic production in the country.

In 2012, IBGE claimed that were planted 82.507 ha of grapes, of those, 80.630, were cropped, that is about 1.455.809 ton. Emater claims that the organic grapes production area in Rio Grande do Sul in 2011 was about 517 ha. But, nowadays, there are no official data about the organic and biodynamic wine industry in Brazil, but it is obviously very small. Because of that, this project aims to identify the organic and biodynamic productions located south in Brazil; as well as their motivation to start doing this kind of management. Also, it is our goal to understand the main obstacles between farmers and certification mechanisms. The south region was chosen because it is the biggest grape and wine production area in Brazil.

This way, for us to reach the proposed goals, this article is sectioned in three parts. Next chapter, will be introduced the methodology, the results and discussions around it all. We'll propose a definition and classification for the identification of biodynamic and organic producers. And in the end, the last section has some final considerations and some conclusion about this whole activity.

\section{Methodology, results and discussion}

For the identification of biodynamic and organic producers, key informants were contacted. Those informants are companies that market that kind of product. With that information, case studies were conducted, since every producer was treated as an unity to be analyzed. Case studies consist on a method of research that allows deeper analysis from the object in question, that method, most of the time does not count with quantitative or statistical analysis. While the goal was to find out the motivation and aspiration that led them to adopt this process, the analysis was quantitative. To that end, the methodological processes used were open and semi-structured surveys, field diaries and observations.

On the south region, we found different types of wine producers that grow many vitis vinifera varieties through organic and biodynamic management, they are on these categories:

I. Vitis Vinifera producers by organic or biodynamic management, who does not vinifie and sell his whole production.

II. Vitis vinifera producers by organic or biodynamic management, Who vinifies part of his production and sells another.

III. Vitis vinifera producers by organic or biodynamic management, Who vinifies all of his production.

IV. Organic or biodynamic vitis vinifera buyers, for vinification purposes.

V. Conventional vineyard in conversion to organic or biodynamic processes.

IV. Organic or biodynamic vineyard under implementation.

According to the features highlighted, it's possible to set up the following table:

All the above organic and biodynamic producers that were interviewed adopted this system in order to offer a differentiated product for a growing market. The consumers group is composed by people that are worried about health and environmental preservation, also biodynamic producer Maurício Ribeiro stated the expectation of achieving authentic products. Jefferson Sancineto Nunes, enologist and agronomist responsible for Santa Augusta vineyard, points as his main obstacle on biodynamic viticulture the lack of labour supply specialized on those practices, or even wanting to learn about them. However, organic producers report difficulty on the certificates, due to the innumerous demands of organic products legislation in Brazil, and the huge costs regarding services provided by certifiers.

\section{Final considerations and conclusions}

We have found six types of producers of organic and biodynamic wines; this group has distinct configurations on their strategies on wine making. The 10 producers where classified this way: one of them is type 1, located in RS; two of them were classified as type 2, both located in $\mathrm{RS}$; one producer is type 3 , located in SC, with two vineyards in the same geographic region of SC, but in different cities; three producers are listed as type 4, Marco Danielle vinified biodynamic grapes just once in 2011; one producer tagged as type 5, which owns the only vineyard located at the Campanha, south end region of RS. Finally, until this moment, just two producers are in deployment phase, one of them in SC and the other in RS. None organic 
Table 1. Types of organic and biodynamic producers identified.

\begin{tabular}{|c|c|c|c|c|c|c|}
\hline Producer/Buyer & Types & Localization & Hectares & Management & Varieties & $\begin{array}{l}\text { Do it have certificate? } \\
\text { Which? }\end{array}$ \\
\hline $\begin{array}{l}\text { Acir Boroto - } \\
\text { Cooperativa de Pro- } \\
\text { dutores Ecologistas de } \\
\text { Garibaldi - (Coopeg) }\end{array}$ & I & $\begin{array}{l}\text { Garibaldi - Serra } \\
\text { Gaúcha (RS) }\end{array}$ & 4 ha & Organic & $\begin{array}{l}\text { Sauvignon Blanc e } \\
\text { Moscato }\end{array}$ & $\begin{array}{l}\text { Yes } \\
\text { COOPEG }\end{array}$ \\
\hline De Lucca & II & $\begin{array}{l}\text { Caçapava do Sul - } \\
\text { Serra do Sudeste } \\
\text { (RS) }\end{array}$ & 9,5 ha & Organic & $\begin{array}{l}\text { Cabernet Sauvignon, } \\
\text { Merlot, Pinot Noir, } \\
\text { Chardonnay, Tannat, } \\
\text { Barbera d'alba } \\
\text { piemont, Peverella }\end{array}$ & $\begin{array}{l}\text { Yes } \\
\text { IMO PRO } \\
\text { CONTROL }\end{array}$ \\
\hline Maurício Ribeiro & II & $\begin{array}{l}\text { Nova Pádua - Serra } \\
\text { Gaúcha (RS) }\end{array}$ & 1,8 ha & Biodynamic & Pinot Noir & No \\
\hline Santa Augusta & III & $\begin{array}{l}2 \text { vineyards located } \\
\text { in the Midwest } \\
\text { of Santa Catarina } \\
\text { (SC) }\end{array}$ & $\begin{array}{l}10 \text { ha } \\
\text { (Videira) } \\
\text { e } 6 \text { ha } \\
\text { (Água } \\
\text { Doce) }\end{array}$ & Biodynamic & $\begin{array}{l}\text { Cabernet Franc, } \\
\text { Cabernet Sauvignon, } \\
\text { Merlot, Pinot Noir, } \\
\text { Chardonnay and } \\
\text { Sauvignon Blanc, } \\
\text { Moscato Branco, } \\
\text { Moscato Giallo, } \\
\text { Montepulciano, } \\
\text { Malbec }\end{array}$ & No \\
\hline Marina Santos & IV & & $\mathrm{x}$ & Organic & $\begin{array}{l}\text { Cabernet Sauvignon } \\
\text { and Barbera }\end{array}$ & No \\
\hline Hex von Weine & IV & $\begin{array}{l}\text { Picada Café - Serra } \\
\text { Gaúcha (RS) }\end{array}$ & $\mathrm{x}$ & Organic & $\begin{array}{ll}\text { Vinifie } & \text { Cabernet } \\
\text { Sauvignon } & \end{array}$ & $\begin{array}{l}\text { Yes } \\
\text { ECOVIDA }\end{array}$ \\
\hline Marco Danielle & IV & $\begin{array}{l}\text { Caxias do Sul - } \\
\text { Serra Gaúcha (RS) }\end{array}$ & $\mathrm{x}$ & Biodynamic & $\begin{array}{l}\text { Vinified Pinot Noir } \\
\text { biodynamic, } 2013\end{array}$ & \\
\hline $\begin{array}{l}\text { Jair Bednarz e José } \\
\text { Bissolotti }\end{array}$ & $\mathrm{V}$ & $\begin{array}{l}\text { Santana do Livra- } \\
\text { mento - Campanha } \\
\text { (RS) }\end{array}$ & 1,25 ha & $\begin{array}{l}\text { Conventional } \\
\text { for Organic }\end{array}$ & $\begin{array}{l}\text { Cabernet Sauvignon, } \\
\text { Merlot and Tannat }\end{array}$ & No \\
\hline $\begin{array}{l}\text { Arno Kroeger e Ju- } \\
\text { liana Kroeger }\end{array}$ & VI & Urupema (SC) & 2 ha & Biodynamic & & No \\
\hline Jaime E. Fensterseifer & VI & & 1 ha & Biodynamic & $\begin{array}{l}\text { Merlot, Pinot Noir } \\
\text { and Chardonnay }\end{array}$ & No \\
\hline
\end{tabular}

Source: elaborated by the author

or biodynamic producers of vitis vinifera were found in Paraná, the third state that composes the South of Brazil. All of the organic and biodynamic producers interviewed claim, as main incentive, adopting this methods with the goal of offering an exclusive product for a growing market.

\section{References}

[1] Howard, A. Um Testamento Agrícola. Editora Expressão Popular. São Paulo, (2012)

[2] Khatounian, C. A. A reconstrução ecológica da agricultura. Botucatu, SP: Agroecológica, (2001)
[3] Jovchelevich, P. Rendimento, qualidade $e$ conservação pós-colheita de cenoura (Daucus carota L), sob cultivo biodinâmico, em função dos ritmos lunares. Dissertação apresentada à Faculdade de Ciências Agronômicas da UNESP. Botucatu, SP, (2007)

[4] Steiner, R. Fundamentos da agricultura biodinâmica. Editora Antroposófica. São Paulo, (1993)

[5] Penteado, S. R. Agricultura Orgânica. Série Produtor Rural Edição Especial. USP/ESALQ. Piracicapa, SP. (2001) 